\title{
Cancer Cell Growth: - A Mini-Review Part-4: First threat (atherosclerotic lesions)
}

\section{Cemil Koyunoğlu}

Energy Systems Engineering Department, Engineering Faculty, Cinarcik Road 5th km, Central Campus, Yalova University, 77200, Yalova, Turkey. Correspondence Author: Cemil Koyunoğlu, Energy Systems Engineering Department, Engineering Faculty, Cinarcik Road 5th km, Central Campus, Yalova University, 77200, Yalova, Turkey

Received date: March 02, 2021; Accepted date: March 15, 2021; Published date: March 20,2021

Citation: Koyunoğlu C. (2021) Cancer Cell Growth: - A Mini-Review Part-4: First threat (atherosclerotic lesions). Clinical Medical Reviews and Reports 3(4); DOI:10.31579/2690-8794/075

Copyright: (C) 2021 Cemil Koyunoğlu, This is an open access article distributed under the Creative Commons Attribution License, which permits unrestricted use, distribution, and reproduction in any medium, provided the original work is properly cited.

\begin{abstract}
The first 3 issues about cancer cells have been tried to explain -in the author papers- how the cells grow by using more energy in the tissue or organ compared to other cells, with the justification of scientific sources. The 4th series of articles will include detailed determinations about the initial threat of a cell growing in an organ or tissue to the organ or tissue by multiplying more than other cells. When a cell proliferates to a sufficient number of cells as mentioned in previous chapters, it begins to make its first threat. It fulfills this cell threat by expressing more than 100 disease forms within the organ. This is a phenomenon that occurs in all living cells. This was even seen in the most primitive invertebrates such as Mollusca and Arthropoda. Examinations of dinosaurs living 100 million years ago revealed the presence of neoplasms. Traces of the above constriction have been found in the cell work done on a 100,000-year-old human fossil. The most important sign of the first threat is phenotypic and genetic change. It creates the impression that it is threatened by a bacterial colony relative to other cells. These cells MIMIC the survival behavior and resistance of unicellular organisms that lived in the same ancient times.
\end{abstract}

Keywords: after proliferation, mimics of a cancer cell, ancient times behavior, first threat, atherosclerotic lesions

\section{Introduction}

However, since their historical imitations are not enough (see Figures 1 and 2), they try to mimic the effects of environmental factors (chemical, biological and physical carcinogenic substances) that create a real response. Thus, the body's defense mechanism becomes unable to separate this uncontrolled creature from inanimate elements. This phase is the most critical. The cell has performed this behavior as a requirement of the defense mechanism it claims. These lesion effects are given below. This study reveals the threat to the reader as a result of the development of a cancer cell, apart from other cells, in relation to previously published topics. The first threat (atherosclerotic lesions) has been brought to the knowledge and attention of relevant researchers and scientists for this purpose.

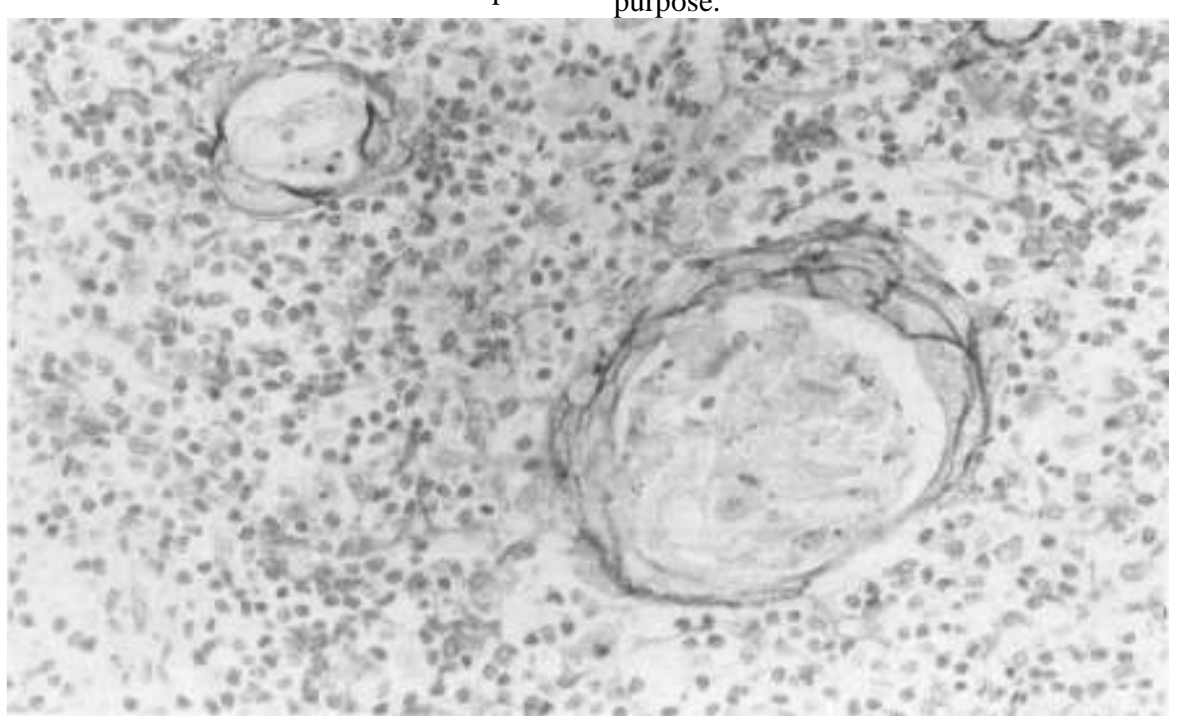

Figure 1. Cells that have proliferated in the pulmonary tissue (benign if there is no tumor if threatened calls "tumor") 1. 


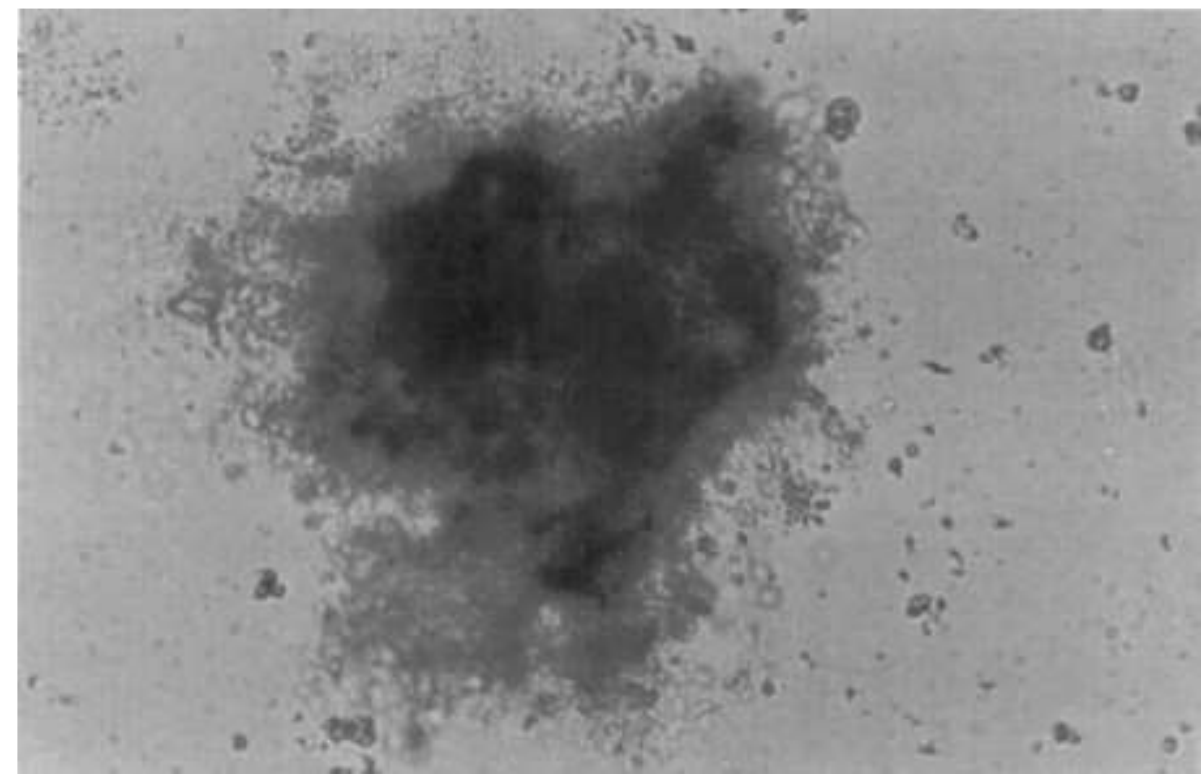

Figure 2. A human gastric carcinoma cell that has proliferated (benign if there is no tumor if threatened calls "tumor") [1].

\section{Atherosclerotic lesions}

Detection of increased cell proliferation is not sufficient in atherosclerotic lesions. However, evidence of cell proliferation levels in different types of human great arteries is still lacking. A study has proven that carotid and coronary arteries make up almost one-third to almost $50 \%$ of the total cell count in lipofibrosis plaques in hematogenous cells. The basis of the impulses "I am the majority" and "will attack me" that I mentioned in the introduction is that the cell that I described in the first 3 sections grows using more energy than other cells. He was one like other cells. However, the symptom of the cell containing the first threat behavior, for example in the aorta, is $15 \%$ of the other cell behaviors. This has experimentally proved that the community formed by single-cell growth, which I suggested in the first 3 chapters, is based on the parent cell, not like other cells. Also, the findings showed that evidence of threat occurs less frequently in the arteries than in the coronary and carotid regions. With the detection of tumor group cells that act dependent on the main cell, they form the tumor in a bell-shaped structure (see figure 3(a) and (b)), and the signs of the threat they give to the organ or tissue (see Figure 4 (a, b, c, d, e)) can be listed as follows [2-5].
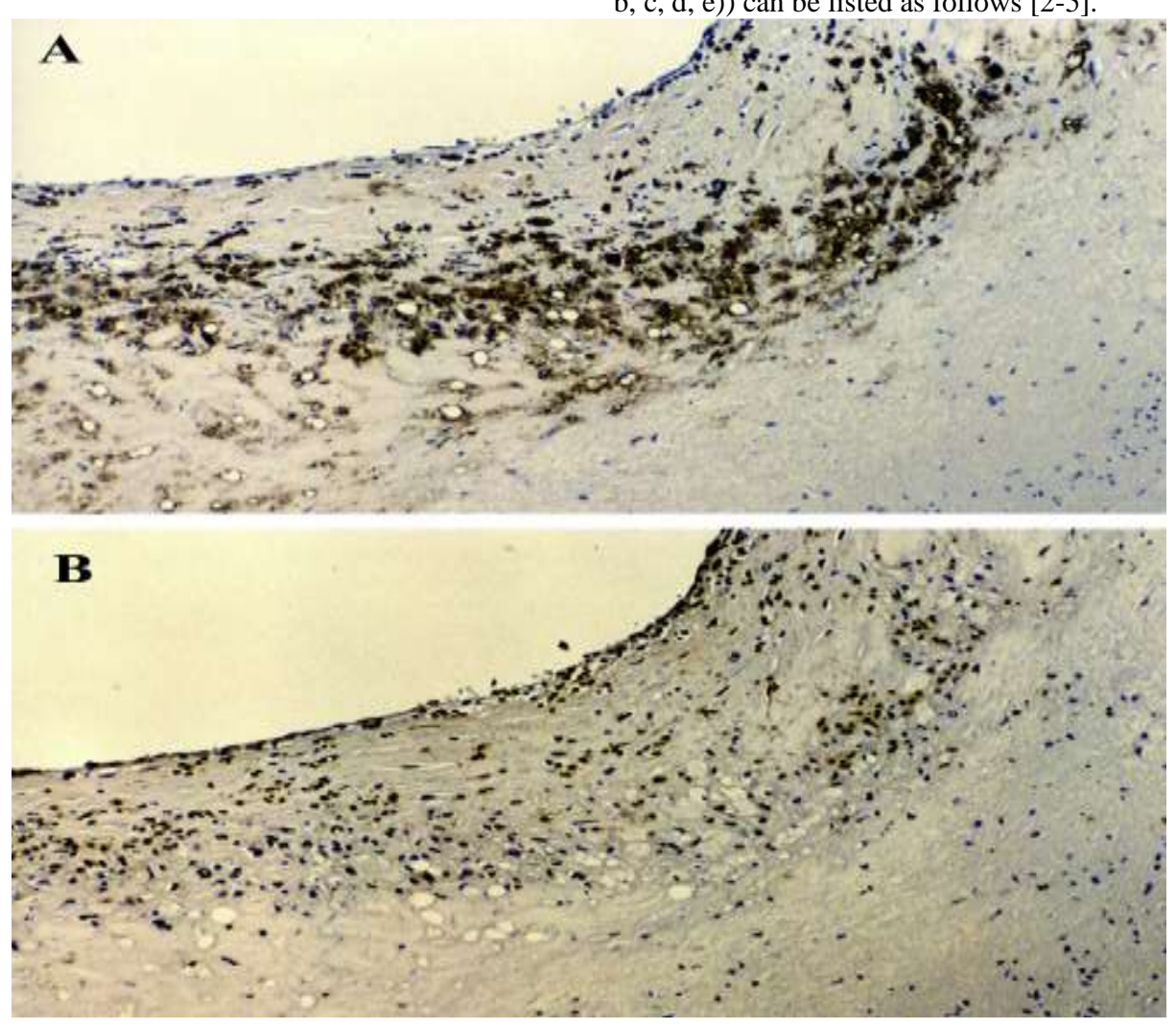

Figure 3 (a) and (b). Bell-shaped image of a group of proliferated cells obeying the parent cell [2]. 

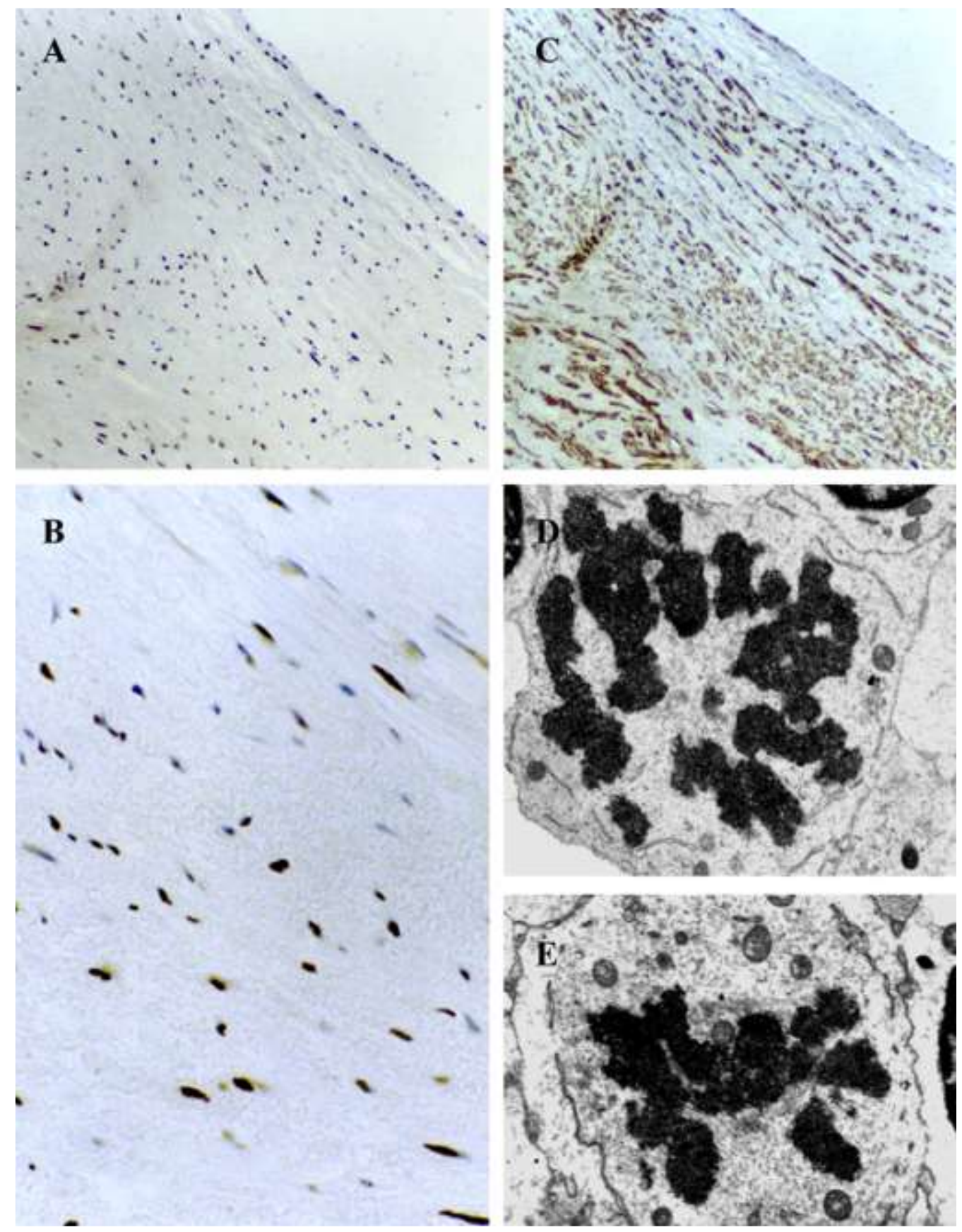

Figure $4(\mathbf{a}, \mathbf{b}, \mathbf{c}, \mathrm{d}, \mathrm{e})$. If the group of cells $(\mathrm{a}, \mathrm{b}, \mathrm{c})$ is not detected, a situation with $\mathrm{d}$ and e will occur [2].

1. Unaffected intima

2. Initial lesions

3. Oily lines

4. Lipofibrous plaques

5. Fibrous plates

This sequence was determined in the carotid and coronary arteries. For example, the maximum number of resident cells was determined for item 4. 0.7 times more proliferation between a healthy carotid artery and a carotid artery with proliferation related to the first threat, while this ratio is 0.9 in the coronary artery, this ratio changes in the carotid artery and coronary artery cells with tumor growth, respectively, 11 and 11, It attracts attention with 2 values. The authors commented that this study is the first experimental study in this field [2].

\section{Conclusions}

These findings are important. The first threat of cancer cells can be determined by methods such as imaging techniques. Besides, the mother cell, mentioned in the introduction, imitating physical and chemical substances is another research subject that should be considered.

\section{References}

1. Junior, S. C. F.; Martins, M. L.; Vilela, M. J., (1998) A growth model for primary cancer. Physica A: Statistical Mechanics and its Applications. 261 (3), 569-580.

2. Orekhov, A. N.; Andreeva, E. R.; Andrianova, I. V.; Bobryshev, Y. V., (2010) Peculiarities of cell composition and cell proliferation 
in different type atherosclerotic lesions in carotid and coronary arteries. Atherosclerosis, 212 (2), 436-443.

3. Juana Virginia, T. V.; Blanca, D. C.; Jaime M. O.; (2017) Atherosclerosis and Cancer; A Resemblance with Far-reaching Implications. Archives of Medical Research, 48 (1), 12-26.

4. B. Ross, J. S.; Stagliano, N. E.; Donovan, M. J.; Breitbart, R. E.; Ginsburg G. S.; (2001) Atherosclerosis and cancer: common molecular pathways of disease development and progression. Ann N Y Acad Sci, 947 (271) 292-293.

5. C. Ramos, K. S.; Partridge, C. R.; (2005) Atherosclerosis and cancer. Cardiovasc Toxicol, 5, 245-255. 